\title{
Afghanistan and ICARDA
}

Ties that Bind
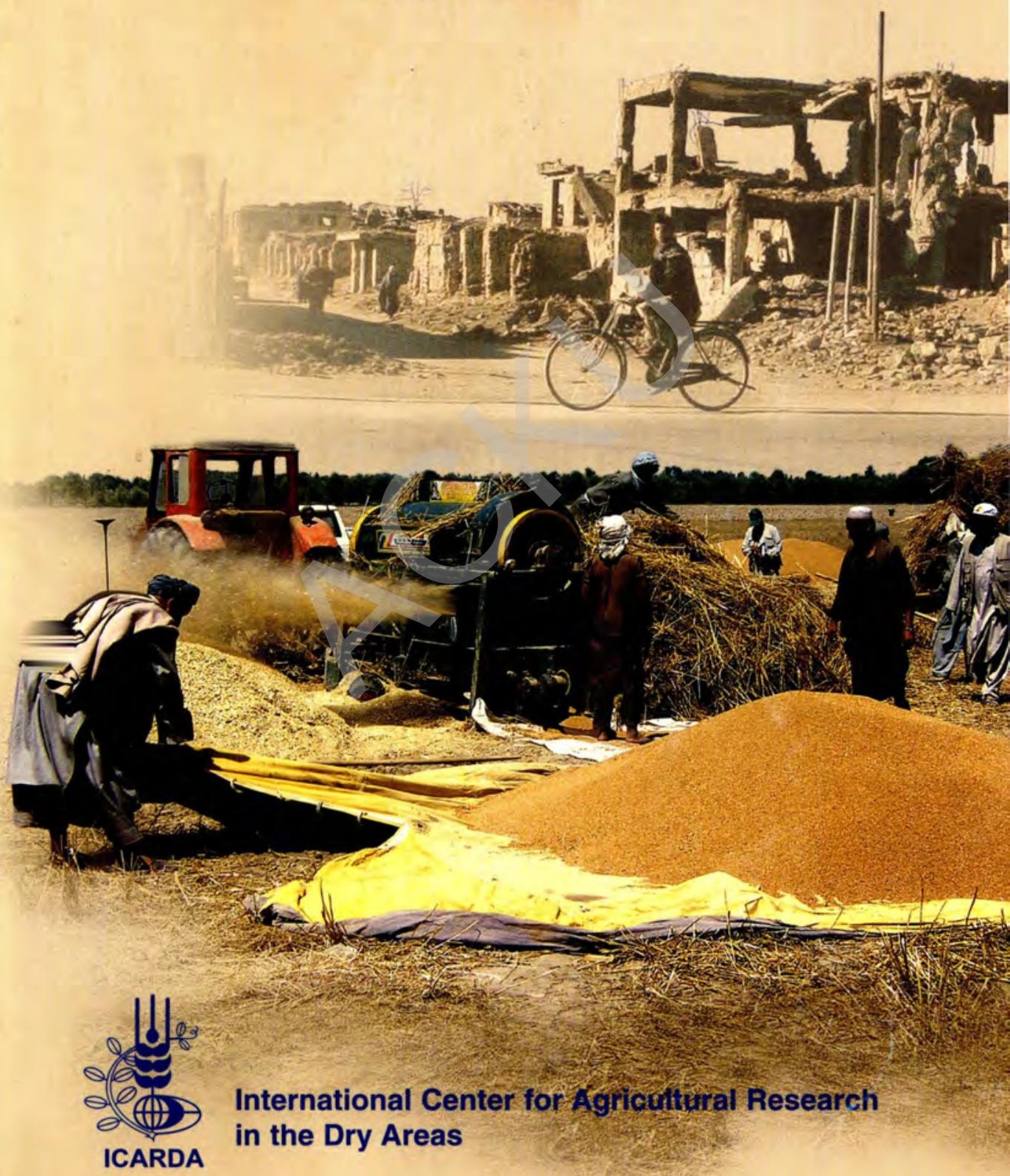


\section{About ICARDA and the CGIAR}

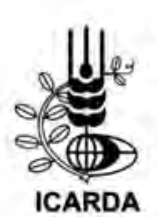

Established in 1977, the International Center for Agricultural Research in the Dry Areas (ICARDA) is one of 15 centers supported by the CGIAR. ICARDA's mission is to improve the welfare of poor people through research and training in dry areas of the developing world, by increasing the production, productivity and nutritional quality of food, while preserving and enhancing the natural resource base.

ICARDA serves the entire developing world for the improvement of lentil, barley and faba bean; all dry-area developing countries for the improvement of on-farm water-use efficiency, rangeland and smallruminant production; and the West and Central Asia and North Africa (CWANA) region for the improvement of bread and durum wheats, chickpea, pasture and forage legumes, and farming systems, ICARDA's research provides global benefits of poverty alleviation through productivity improvements integrated with sustainable natural-resource management practices. ICARDA meets this challenge through research, training, and dissemination of information in partnership with the national, regional and international agricultural research and development systems.

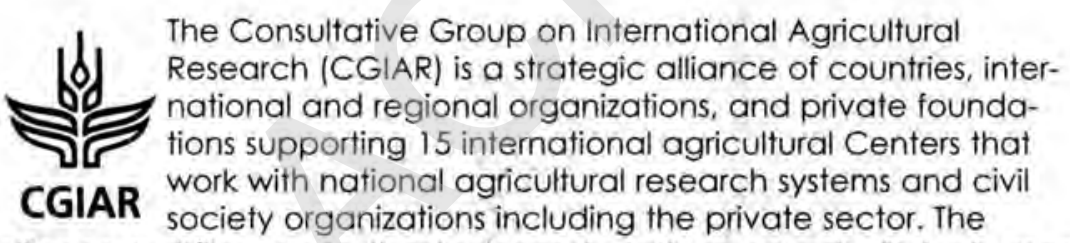

alliance mobilizes agricultural science to reduce poverty, foster human well being, promote agricultural growth and protect the environment. The CGIAR generates global public goods that are available to all.

The World Bank, the Food and Agriculture Organization of the United Nations (FAO), the United Nations Development Programme (UNDP), and the International Fund for Agricultural Development (IFAD) are cosponsors of the CGIAR. The World Bank provides the CGIAR with a System Office in Washington, DC. A Science Council, with its Secretariat at FAO in Rome, assists the System in the development of its research program. 


\title{
Afghanistan and ICARDA
}

\author{
Ties that Bind \\ No. 21
}

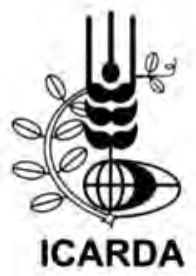

International Center for Agricultural Research in the Dry Areas (ICARDA) 
(C) 2005 International Center for Agricultural Research in the Dry Areas (ICARDA)

All rights reserved.

ICARDA encourages fair use of this material.

Proper citation is requested.

Citation: ICARDA. 2005. Afghanistan and ICARDA. Ties that Bind, No. 21. ICARDA, Aleppo, Syria. iv +20 pp.

ISBN: $92-9127-170-8$

\section{Headquarters}

International Center for Agricultural Research in the Dry Areas

(ICARDA)

P.O. Box 5466, Aleppo, Syria

Tel: (+963) (21) 2213433, 2213477, 2225112, 2225012

Fax: (+963) (21) 2213490, 2225105, 5744622

E-mail: ICARDA@cgiar.org

Website: http://www.icarda.org 


\section{Contents}

Introduction 1

The Power of Partnership 2

Immediate Aid 4

Needs Assessments $\quad 5$

Rehabilitating Research Capability 6

Preserving the Genetic Heritage $\quad 7$

Establishing Regulations for the Seed Industry $\quad 8$

Spreading the Message 9

Short-Term, High-Impact Projects $\quad 10$

Current Projects 14

Human Resource Development 19

Ongoing Committment 20 


\section{FHCRAA Partners and Donors}

\author{
CG Centers: \\ International Center for Agricultural \\ Research in the Dry Areas \\ (ICARDA) \\ International Center for Tropical \\ Agriculture (CIAT) \\ International Center for Maize and \\ Wheat Improvement (CIMMYT) \\ International Potato Center (CIP) \\ International Crops Research \\ Institute for the Semi-Arid Tropics \\ (ICRISAT) \\ International Food Policy Research \\ Institute (IFPRI) \\ International Livestock Research \\ Institute (ILRI) \\ International Plant Genetic \\ Resources Institute (IPGRI) \\ International Water Management \\ Institute (IWMI)
}

Other international insilitutes:

The Asian Vegetable Research and Development Center (AVRDC)

International Centre for

Development Oriented Research in Agriculture (ICRA)

International Fertilizer Development Center (IFDC)

\section{Alghanision:}

Local institutes, particularly the Ministry of Agriculture, Animal Husbandry and Food (MAAHF)

Non-Governmental Orgonizations:

The International Federation of Red

Cross and Crescent Societies (IFRC)

The International Medical Corps

The Aga Khan Development Network

Mission d'Aide au Développement des Economies Rurales en Afghanistan (MADERA)
The Pamir Rehabilitation Bureau Legacy international

SOLIDARITES

Ghazni Rural Support Programme (GRSP) International Mercy Corps (IMC)

Agency for Technical Cooperation and Development (ACTED)

CARE International Helping Afghan Farmers

Organization (HAFO)

Agricultural Development of Afghanistan (ADA)

FOCUS

Concern Worldwide

Catholic Relief Services

The Danish Committee for Aid to

Afghan Refugees (DACAAR)

Islamic Relief Agency (ISRA)

Uniled Nations Agencies:

Food and Agriculture Organization

(FAO)

World Food Program

Unifed States Institutions:

Texas A\&M

Cornell University

University of California, Davis

University of Vermont

Michigan State University

\section{Donors:}

United States Agency for International Development (USAID)

International Development

Research Centre (IDRC)

Department for International

Development (DFID)

Japan International Cooperation Agency (JICA)

OPEC Fund for International

Development 


\section{INTRODUCTION}

\section{fter more than two decades of war and years of crippling $\Delta$ drought, agricultural production capacity and food security Iwere greatly compromised in Afghanistan. The country which}

had once boasted of an agricultural sector that contributed to more than $80 \%$ of the national income was now heavily dependent on food aid from international donors. In the late 1970s, Afghanistan had almost reached self-sufficiency, importing only 2500 tons of cereals, due to an efficient research program that developed and promoted high-yielding, disease-resistant varieties of cereals, horticultural, industrial, and oil crops. There were 19 agricultural research stations in the different agroclimatic zones of the country and the extension department routinely disseminated results to farmers through demonstration plots.

Conflict and drought changed all that. The government infrastructure and research institutes were destroyed. Qualified staff left the country. Equipment in research stations was looted and destroyed. Improved varieties lost their yield potential and succumbed to new races of pathogens. There was no water for irrigation, no pesticides or fertilizers, few roads to transport produce, and, most crippling of all, there was no seed to plant. An agricultural system that had once provided a steady income for about $80 \%$ of the population urgently needed to be revived.

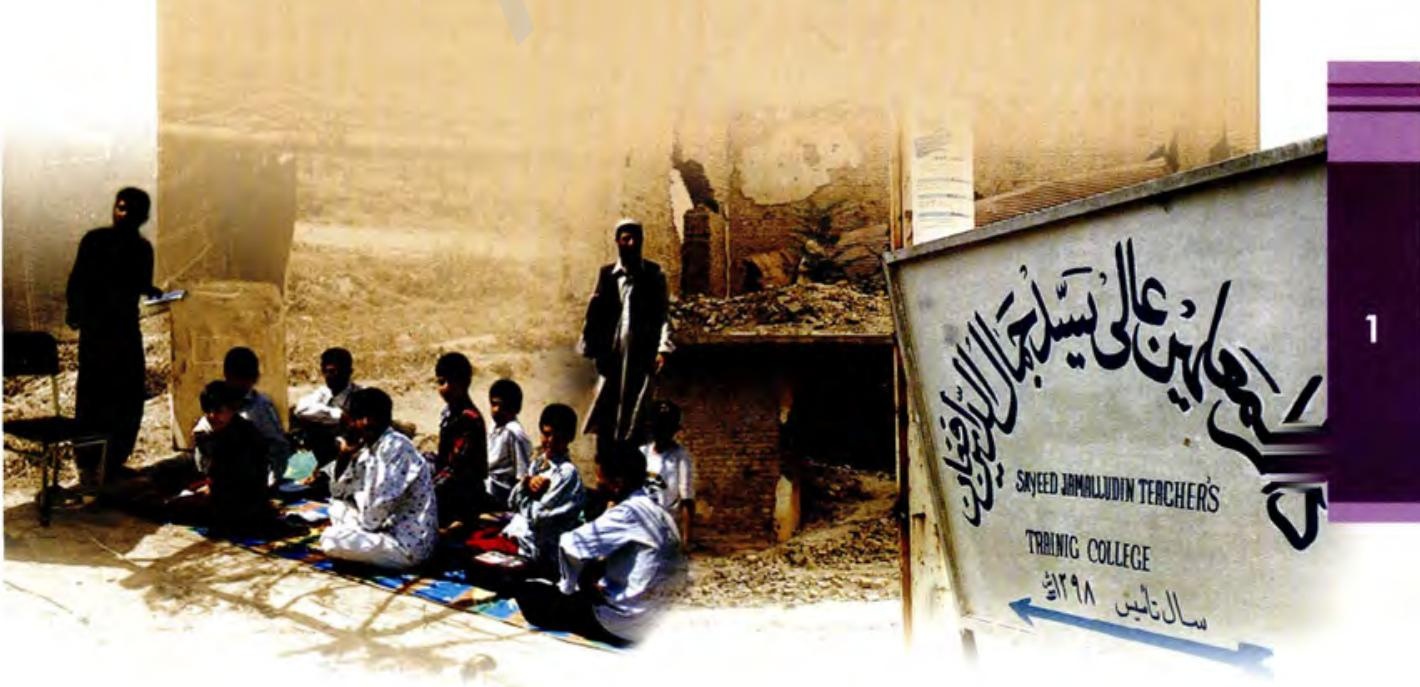




\section{THE POWER OF PARTNERSHIP}

In January 2002, ICARDA, with the support of the United States Agency for International Development (USAID), brought together 74 experts from 34 organizations including the CGIAR centers and other research institutes, relief and development organizations, NGOS, U.S. universities, donor agencies, and the Afghanistan Ministry of Agriculture and Livestock (MOAL) at a meeting in Tashkent, Uzbekistan. The result was the creation of the Future Harvest Consortium to Rebuild Agriculture in Afghanistan (FHCRAA).

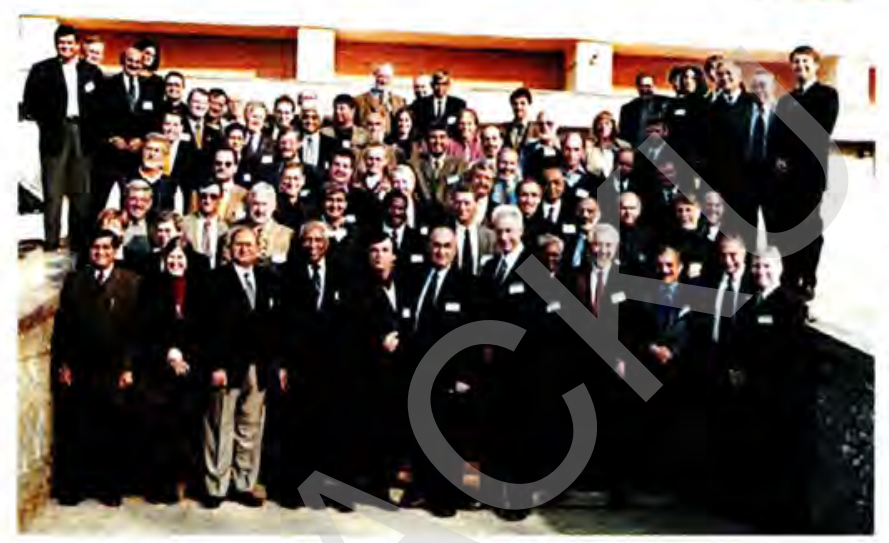

Seventy-four representatives from 34 organizations gathered in January 2002 in Tashkent, Uzbekistan, to help plan the rehabilitation of Afghanistan's agriculture sector.

The Consortium identified four key areas that needed attention: seed systems and crop improvement; soil and water management; livestock, feed and rangeland improvement; and horticulture. With the ultimate goal of restoring Afghanistan's agriculture, the Consortium developed specific objectives and workplans for each area. USAID provided a grant of US $\$ 9.52$ million for the Consortium to provide emergency seed and technical assistance in Afghanistan.

\section{Objectives of FHCRAA}

- Multiply and deliver quality seed of adapted varieties through effective delivery systems to reach affected farmers in time, and to build, with Afghan partners, an efficient regulatory system that enforces standards and promotes the use of high quality seed and varieties 
- Establish a framework and strategy for CGIAR technical assistance, in cooperation with partners, for the development of seed systems and sustainable agricultural production systems in Afghanistan at the central, regional, and local levels

- Restore an enabling environment through capacity building

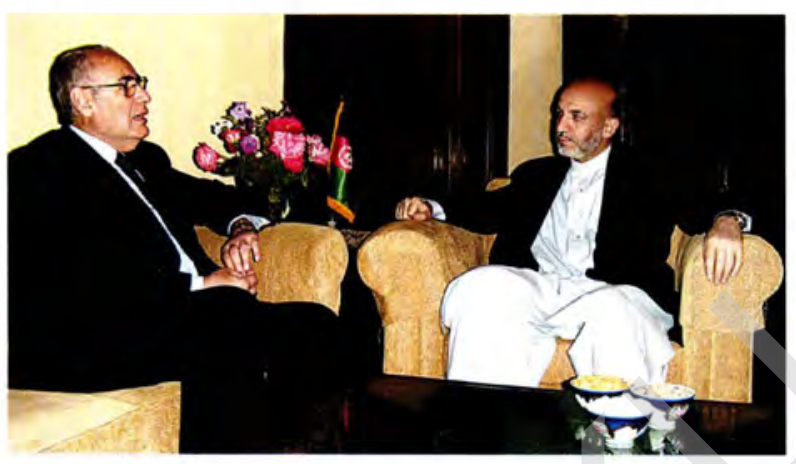

H.E. Mr Hamid Karzai (right), President of Afghanistan, discussed the status of agriculture in his country and the work of the Future Harvest Consortium to Rebuild Agriculture in Afghanistan (FHCRAA). with ICARDA Director General, Prof. Dr Adel El-Beltagy, in Kabul on 7 October 2002.

ICARDA Director General, Prof. Dr Adel El-Beltagy met with H.E. Dr Abdullah Abdullah (right) Minister of Foreign Affairs, Afghanistan, in February 2005 to discuss ways to strengthen the activities of FHCRAA and achieve the goal of rebuilding agriculture in Afghanistan more effectively and speedily.
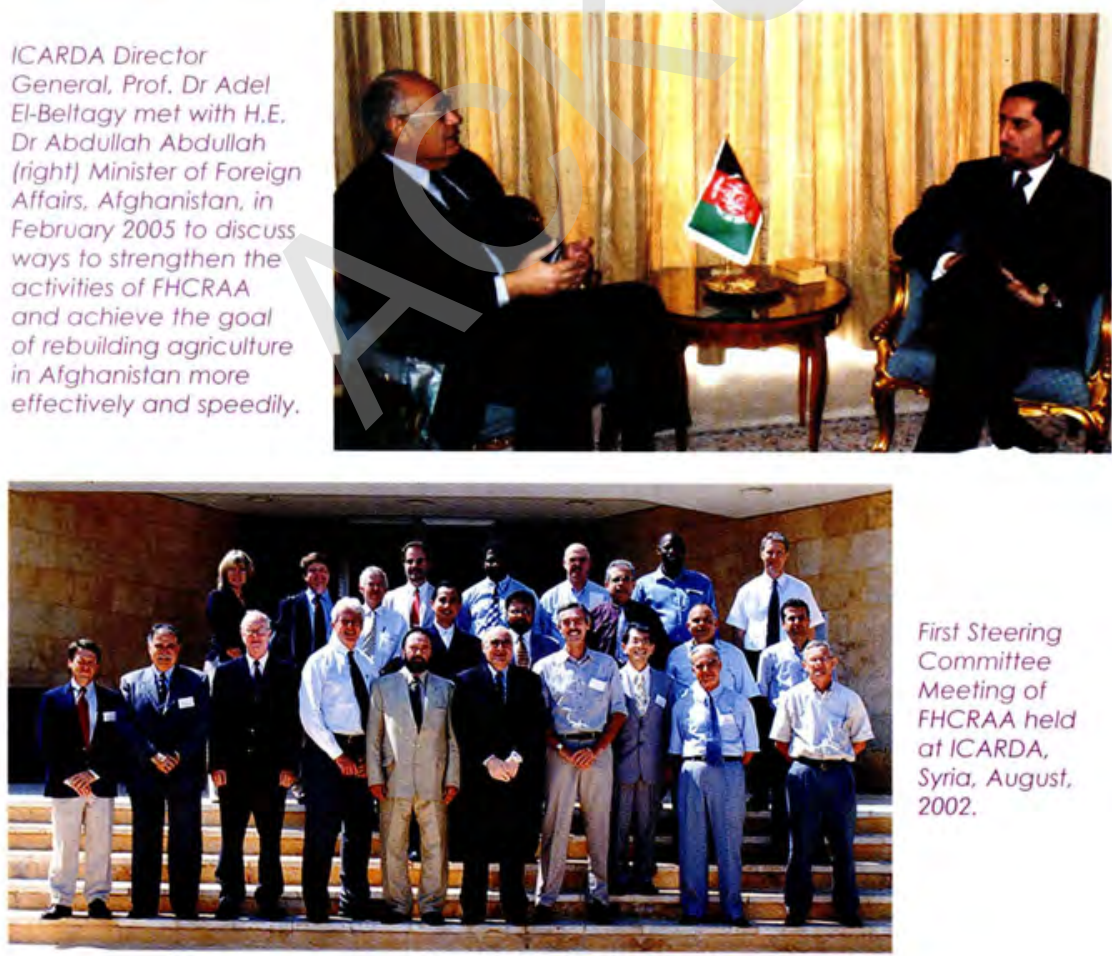

First Steering Committee Meeting of FHCRAA held at ICARDA, Syria, August, 2002. 
province in Afghanistan often passing through mine-littered roads and fields, and checkpoints in villages controlled by warlords. Thousands of farmers willingly answered questions and told their stories of deprivation and heartbreak. The needs assessment teams presented their results to representatives of the Afghanistan Ministry of Agriculture and Livestock (MOAL), U.S. universities, NGOs, the Food and Agriculture Organization (FAO) of the UN, the private sector, and the CGIAR Centers at a meeting held at ICARDA on 18-20 November 2002.

The seed systems and crop improvement assessment reported that increasing crop productivity at the household level would substantially reduce rural poverty and hunger for families whose debt insecurity averaged about US $\$ 800$ per household. The soil and water needs assessment listed lack of credit, nutrient deficiency, seeds, and water as the major constraints faced by farmers. They also noticed that farmers needed more information on effectively managing their water resources and using fertilizers. The livestock, feed and rangelands assessment recommended institutional strengthening and human capacity building, integrated small ruminant production and animal health management, and improved dairy production for households. The horticulture and marketing assessment presented horticultural crops as the best option for replacing poppy production in Afghanistan. While there is a market for the traditional Afghan horticultural crops, many of the country's cultivars and practices are unacceptable. The lack of roads, transportation, and storage facilities also limits horticulture from returning to its previous status of contributing 30-50\% to Afghanistan's export earnings.

\section{REHABILITATING RESEARCH CAPABILITY}

During the civil war, Afghanistan lost its research stations and the national genebank that held the country's agricultural heritage. ICARDA, with help from USAID, rebuilt five agricultural stations in five provinces: Kabul, Baghlan, Kunduz, Takhar, and Nangarhar. The stations develop and evaluate new crop genotypes for distribution throughout the region and farmers visit the stations to select lines suitable for their fields. In 2003, experimental plots of wheat, barley, chickpea, lentils, faba bean, tomato, onion, and pepper were harvested for the first time in many years. The stations also serve as centers for small business 
development, market creation, crop improvement, technology transfer, and training for farmers. Three seed quality testing laboratories in Kabul, Herat, and Nangarhar and several satellite testing stations in Kunduz, Mazar, and Baghlan were also established to ensure that marketed seeds are of superior quality. Meteorology stations were installed in six provinces and Ministry and Meteorology Department staff were trained.
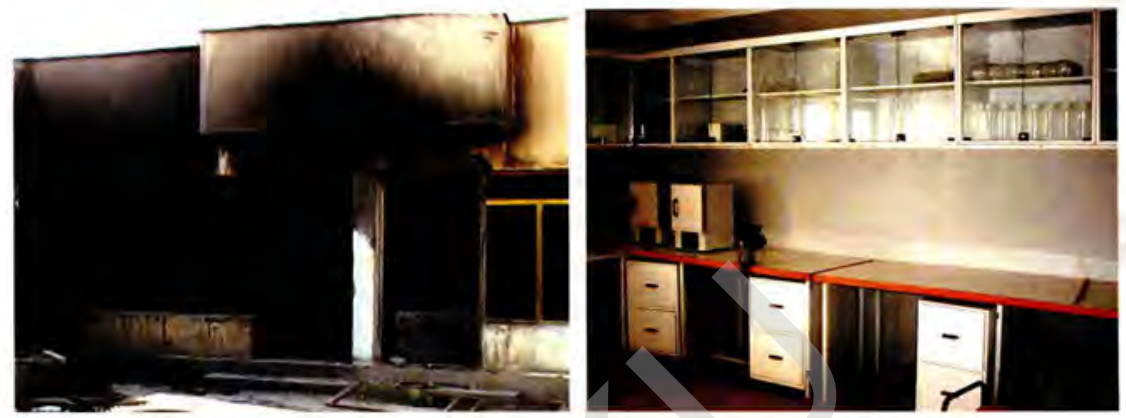

Badam Bagh seed testing station, near Kabul-before (left) and after refurbishing.

Several international nurseries were planted for testing yield, drought and cold tolerance, and disease resistance in a variety of crops. This international nursery program will identify adapted germplasm for Afghanistan's varied agroecological zones. A variety maintenance program has been initiated in Darul Aman, Baghlan, Kunduz, and Taloqan to maintain varietal purity and initiate seed multiplication of improved varieties. ICARDA produced 171,771 fruit saplings and 13,134 non-fruit saplings in four research stations for distributing to farmers in the area.

\section{PRESERVING THE GENETIC HERITAGE}

In September 2002, the international media reported that looters had destroyed Afghanistan's largest crop seed collection. The seed was dumped so that looters could take the plastic containers in which samples were stored. The FHCRAA has begun to repatriate seed from duplicate collections around the world. So far seed samples of 41 barley landraces and $250 \mathrm{~kg}$ seed of several cereal and legume landraces have been sent back to Afghanistan.

The Consortium has also organized collection trips to try to replace lost seed, landraces and wild relatives of important crop species. For 
example, some 60 almond, 47 pistachio, 14 pomegranate, and 16 melon samples were collected. Fruit tree nurseries were established on the research stations in Nangarhar, Baghlan, Kunduz, and Takhar provinces which resulted in the production of 183,000 grafted saplings of different fruit trees. These were distributed to farmers and local authorities for the establishment of orchards. In 2005, ICARDA established 95 orchards in northeastern Afghanistan.

\begin{tabular}{|c|c|c|}
\hline \multicolumn{3}{|c|}{$\begin{array}{l}\text { Germplasm from Afghanistan preserved in the genebank of the Consortium member } \\
\text { of the CGIAR. }\end{array}$} \\
\hline Centers & Crop collections & Number of accessions \\
\hline CIAT & Beans & 73 \\
\hline CIMMYT & Maize, wheat & 21 \\
\hline ICARDA & $\begin{array}{l}\text { Genetic resources collection, wheat, } \\
\text { barley, lentil, chickpea, forage legumes }\end{array}$ & 2217 \\
\hline ICRISAT & Chickpea, small millets, sorghum & 723 \\
\hline IITA & Genetic resources collection & 77 \\
\hline ILRI & Genetic resources collection & 23 \\
\hline IRRI & Rice collection & 69 \\
\hline
\end{tabular}

\section{ESTABLISHING REGULATIONS FOR THE SEED INDUSTRY}

Like its physical infrastructure, Afghanistan's administrative structures and policy guidelines also suffered serious damage leaving farmers with unsuitable varieties and poor-quality seed that failed to germinate. To ensure quality seed production in Afghanistan, regulatory guidelines needed to be established for production, import, and distribution of seed and planting materials. In May 2002, more than 80 participants helped develop a Code of Conduct for seed production and marketing. The Code takes into account Afghanistan's specific conditions while urging the nation to participate in developments in the seed industry taking place around the world. Afghanistan's Acting Interim Government adopted this Code of Conduct. A National Seed Policy and a Seed Law are also being finalized with support from FAO. 


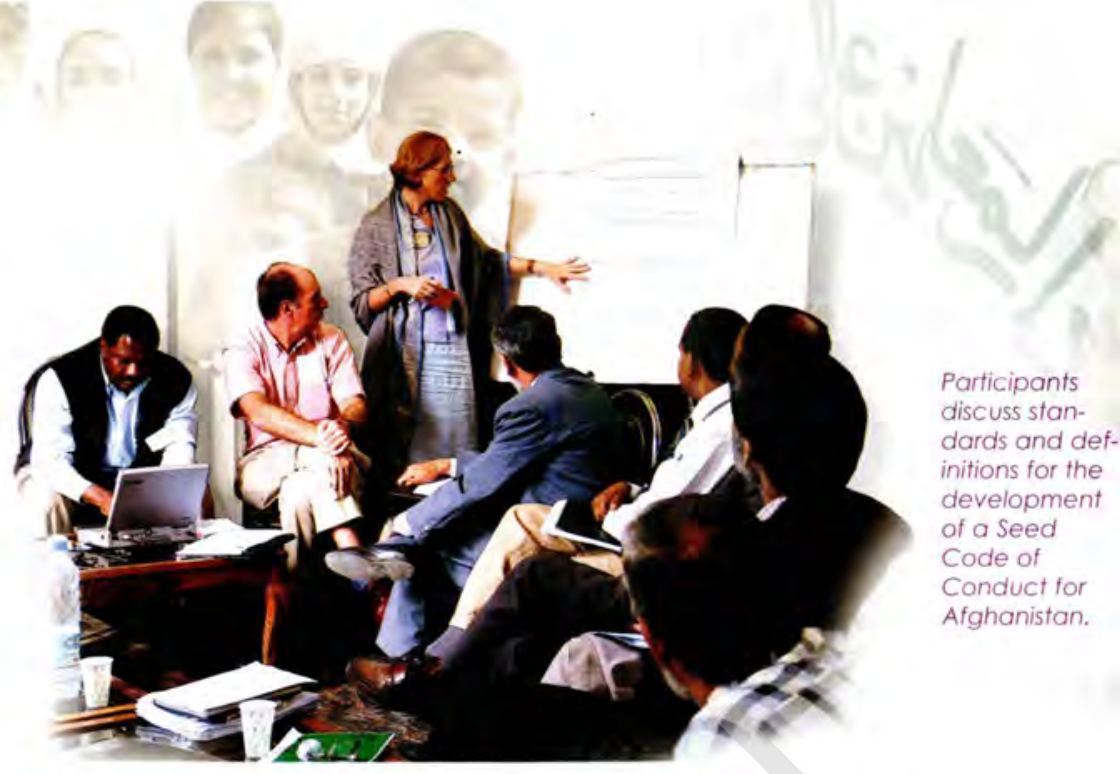

\section{SPREADING THE MESSAGE}

Partly due to a low literacy rate of only $31 \%$, Afghans mostly depend on the radio for information, entertainment, and news from other provinces and the central government. The FHCRAA is capitalizing on this dependence by producing a weekly program on agriculture that is aired on 50 government and private radio stations all over the country. The program features interviews with farmers in their fields, researchers, and extensionists, and provides information on technologies for improved agricultural production. Farmers, who now identify closely

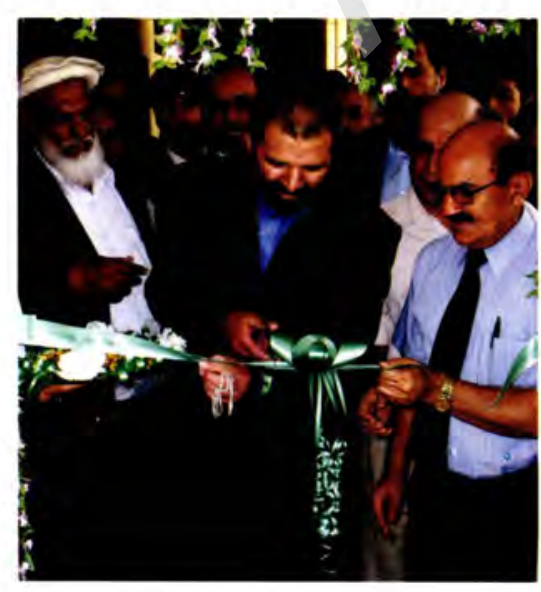

with the program, usually meet in groups to listen to the broadcasts. Farmers from Nangarhar, Warkdak, and Maidan Shar have praised the program for addressing issues that concern them.

Afghanistan Minister of Agriculture and Livestock. (MOAL). H.E. Mr Sayed Hussain Anwari, cuts the ribbon on the Ministry's refurbished recording studio, assisted by Dr Nasrat Wassimi (right), Executive Manager of ICARDA's Kabul office, and Mr Amir Muhammad Safi (left), Head, MOAL Communication Section, on II September 2003 in Kabul. 
The Consortium also organized a five-day workshop in Kabul on agricultural journalism in 2003. Radio reporters from 13 provinces were trained in basic journalism, interview techniques, and creative production. Each participant also selected a specific topic such as water management or fertilizer application, conducted interviews with appropriate agricultural resource people, and produced a 3-minute script that was recorded on CDs.

\section{SHORT-TERM, HIGH-IMPACT PROJECTS}

Eight short-term, high-impact projects funded by USAID complemented other efforts to shift Afghanistan from emergency relief to an economically productive, sustainable, and diverse rural economy. ICARDA managed this grant program that awarded a total of US\$1.25 million and ended in August 2003.

\section{POTATO SEED PRODUCTION AND MULTIPLICATION}

The International Potato Center (CIP) increased the supply of virus-free potato seed in Afghanistan for local needs as well as future export to neighboring countries by developing a farmer-based seed multiplication system. The project successfully trained farmers and tested new varieties in Jalalabad, Kabul, and Bamyan.

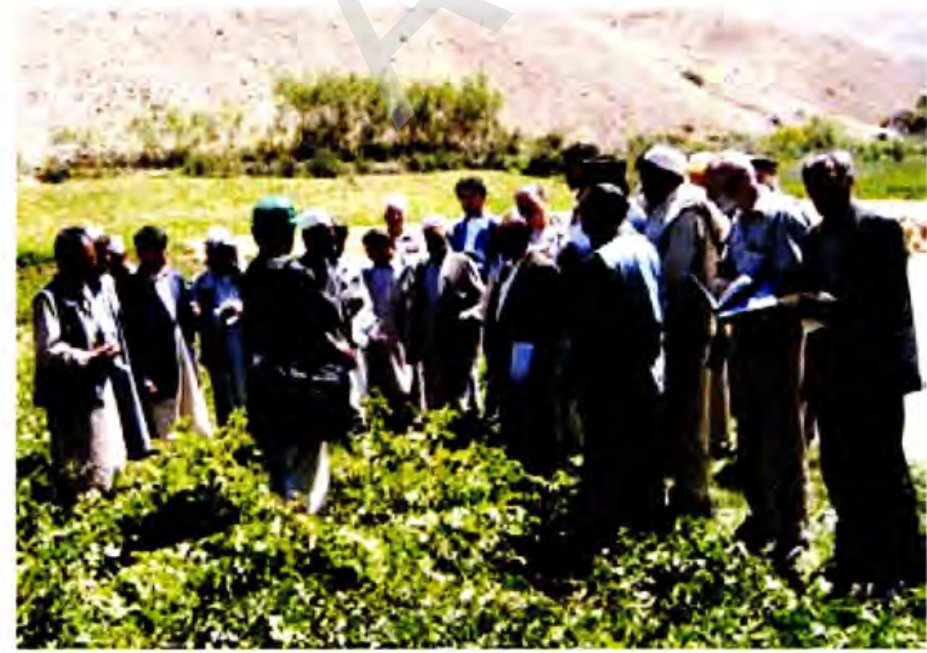

Seed potato production training in Bamyan province. 


\section{SUSTAINABLE MAIZE SYSTEMS: SEEDS FOR PEACE}

The International Center for Wheat and Maize Improvement (CIMMYT) scientists implemented an open-pollinated maize improvement program. Researchers identified candidates for training and chose 20 locations for trials around Afghanistan. CIMMYT distributed seeds for trials and arranged for the planting of experiments near key villages. Farmer survey documents were prepared and a manual in Pashto and Dari was produced for farmers and extension agents. After training, farmercooperators were able to observe production problems and identify maize populations for on-farm commercialization.

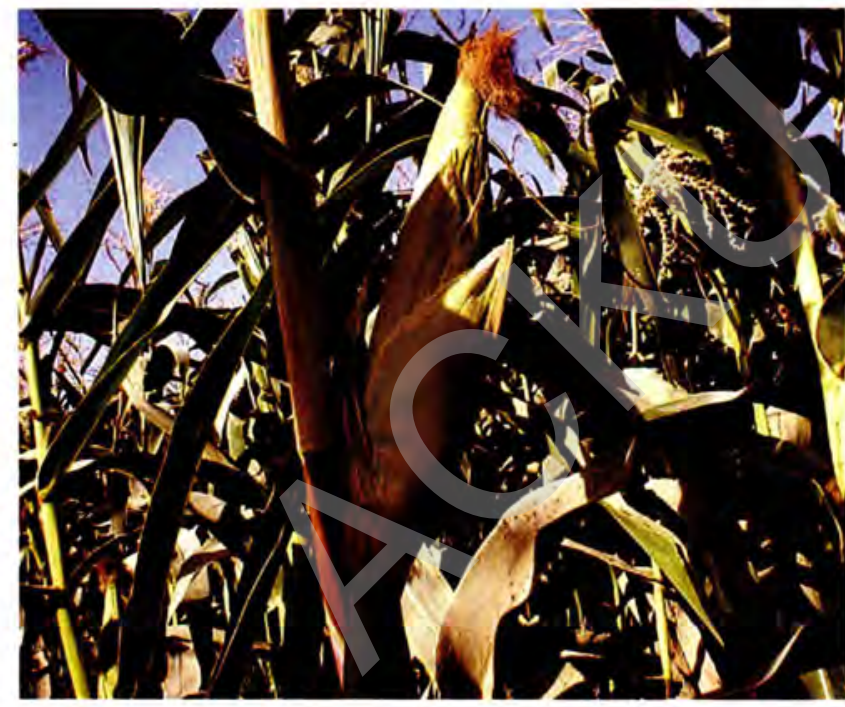

Maize cultivar in Kunduz Province.

\section{BUILDING HUMAN RESOURCE CAPACITY IN WHEAT AND MAIZE RESEARCH}

CIMMYT contributed to building human resource capacity by training around 30 scientists. Five Afghan scientists participated in the wheat improvement training course, and two attended the advanced agronomy course in Mexico. One maize breeder attended the advanced maize improvement course and two wheat scientists joined the CIMMYT-Turkey office for training. An in-country training course was held for 20 Afghan scientists. 


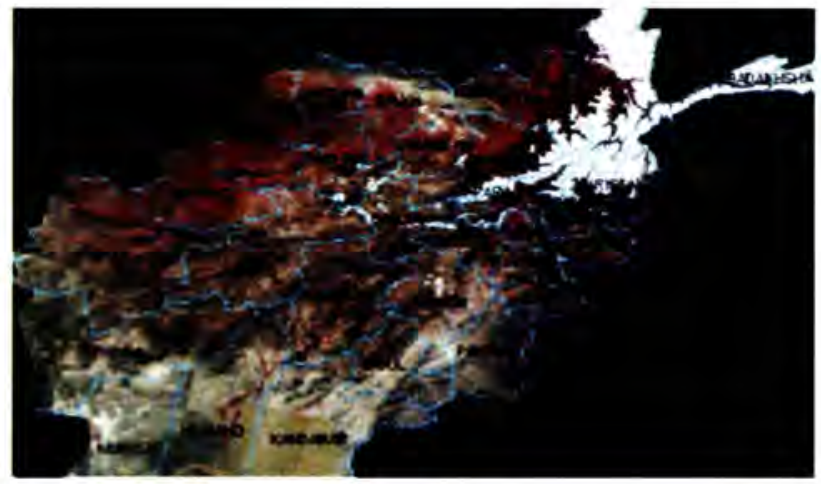

\section{RANGELAND INFORMATION PRODUCTS FROM REMOTELY SENSED IMAGERY}

Michigan State University utilized satellite remote sensing and Geographic Information Systems (GIS) technology to create detailed maps to improve rangeland management. GIS experts accessed and overlaid Moderate Resolution Imaging Spectroradiometer (MODIS) imagery and digital elevation model (DEM) data layers and integrated the information from Landsat images for all of Afghanistan from May 2002. The on-ground data validation study began in June, and despite enormous security and logistical problems, was a success. The crew traveled around the rainfed regions of Afghanistan with Global Positioning System (GPS), video and computing equipment to compare and validate on-ground forage productivity with Landsat-based estimates. The resulting maps along with training in interpretation and utilization of the data for improved rangeland management were provided to farmers and agricultural professionals at the MSU website.

\section{AGRICULTURAL PRODUCTION ON DEGRADED SALNE LAND}

Drought has reduced surface water supplies and the bulk of the irrigation systems which helped to produce more than $80 \%$ of Afghanistan's food supply in the past. The International Center for Biosaline Agriculture (ICBA), based in the United Arab Emirates, provided apprenticeships for extension agents to improve their basic skills in designing and operating improved irrigation systems suitable for saline soils and water. Three trainees worked at ICBA for six weeks and attended a two-month water and soil management course at ICARDA. 


\section{FARM WATER MANAGEMENT AND IRRIGATION}

Groundwater resources have been overexploited and the water tables have dropped significantly over large areas of Afghanistan causing wells to go dry. Soil salinization and degradation is a priority issue in five provinces - Helmand, Ghazni, Faryab, Shaberghan, and Kandahar. The Danish Committee for Aid to Afghan Refugees (DACAAR) worked to introduce best management practices for farm water management and irrigation. Their project commitment was fulfilled by training eight Afghan scientists in best water management practices at the water and soil management course at ICARDA.

\section{BEST MANAGEMENT PRACTICES FOR WATER AND SOIL.}

A team from Cornell University, Ithaca, New York held a workshop on "Best Management Practices for Water and Soil" at the College of Agriculture, Kabul University. Seventy-four Afghans attended the first day's course on water management and approximately 200 attended the second day's training in crop and soil management. The researchers also organized a traveling workshop for 35 participants. The participants visited irrigation systems and farms in Baghlan and Balkh provinces, and toured the Parwan irrigation project. During the workshop, the investigators conducted field schools to help farmers better understand water and nutrient management practices. Handouts in local languages on key factors in wheat production, soil nutrient deficiencies, wheat diseases and water management were distributed at the workshop.

\section{BUILDING CAPACITY TO CONTROL SUNN PEST INFESTATIONS}

The indiscriminate use of pesticides has created resistance in and killed the natural enemies of Sunn Pest. ICARDA and the University of Vermont addressed the Sunn Pest problem by providing integrated pest management training to Afghan agronomists, farmers and NGOs. The training covered biological and behavioral knowledge of Sunn Pest, farming practices, host-plant resistance, entomopathogenic fungi and the use of conventional pesticide. ICARDA also conducted an in-country training course. Crop production guides on insect management were translated into Dari and Pashto. The group also delivered a Sunn Pest Management Guide to the Central Asia Development Group (CADG). 
based in Afghanistan, which enabled local farmers to save 32,000 hectares of irrigated wheat worth US $\$ 12.8$ million. Researchers also reestablished the Kabul University Entomology Laboratory and furnished it with equipment purchased through this grant.

\section{CURRENT PROJECTS}

\section{REBUILDING AGRICULTURAL MARKETS PROJECT (RAMP)}

RAMP aims to reinvigorate the market chain by introducing new crops, facilitating information and technology exchanges, and creating employment for farmers and other rural folk. ICARDA and the International Potato Center (CIP) are implementing four projects funded by USAID under RAMP in 27 districts in 5 provinces of Afghanistan.

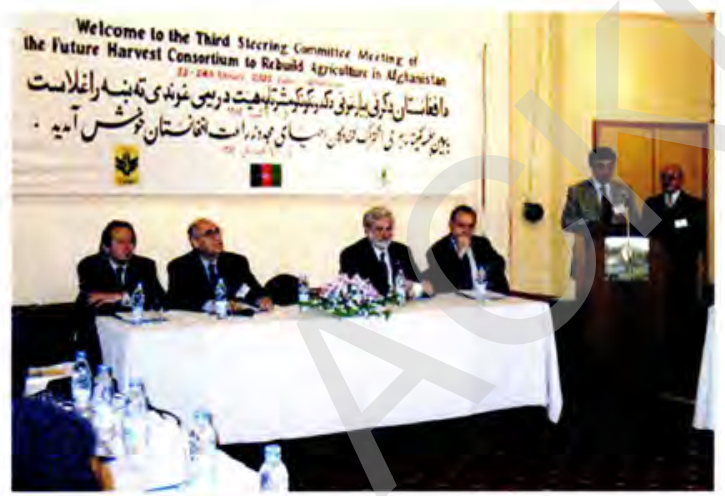

H.E. Mr Obaidullah Ramin fat podium). Afghanistan Minister of Agriculfure. Animal Husbandry and Food opened the FHCRAA Steering Committee Meeting on 23 February 2005 in the company of (seated from left to right) Dr Serge Verniau, FAO Representative in Afghanistan: Prol. Dr Adel El-Beltogy. ICARDA DG and Chair of FHCRAA: H.E. Mr James Moseley. Deputy Secretary. Ministiy of Agriculture, USA; and Dr Richard Hogg, DFID.

\section{DEMONSTRATING NEW TECHNOLOGY IN FARMERS' FIELDS TO FACILITATE} RAPID ADOPTION AND DIFFUSION

The overall aim of this project implemented by ICARDA is to increase agricultural productivity and rural incomes by demonstrating and encouraging the adoption of improved varieties and new technologies. ICARDA conducted 362 demonstrations of wheat, potato, onion, tomato, rice and mung bean to showcase the $30-85 \%$ higher yields of 11 improved varieties. The project organized 27 farmers' field days that attracted 2000 farmers and developed five Best Practice Manuals (one each for wheat, potato, tomato, rice and onions) in Dari and Pashto. The project's activities including field days and training sessions were covered by local radio and TV stations, effectively increasing the audi- 
the project had trained 46 trainers and more than 150 growers in the construction. maintenance, and management of greenhouses. In addition, 10 local technicians were trained in greenhouse manufacturing. An additional five greenhouses in Kabul and 10 in the five targeted provinces of Parwan, Ghazni, Kunduz, Helmand, and Nangarhar were also established in farm-

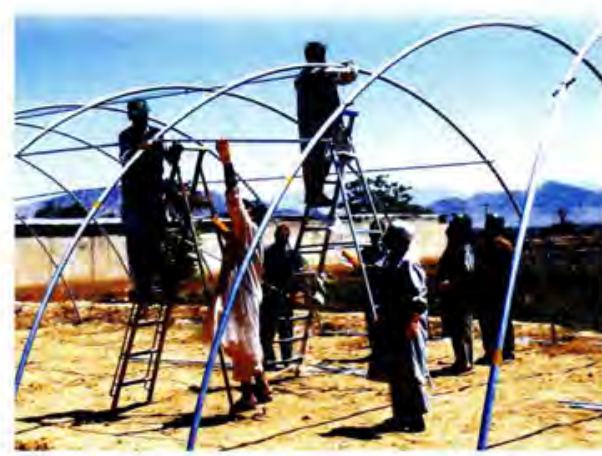

Installation of greenhouses of the Protected Agriculture Center (PAC). Badam Bagh Research Station, in Kabul, Afghanistan.

ers' fields and impressive crops of cucumber and tomato are attracting neighboring farmers. A market survey is being conducted and a database developed to understand the trends in supply, demand, and prices to design crop calendars and market strategies.

\section{CLEAN SEED PRODUCTION, MULTIPLICATION AND MARKETING FOR INCREASED POTATO PRODUCIION IN AFGHANISTAN}

Afghanistan's climate is particularly suited for growing potatoes. But there was no organized seed sector in the country. This project, jointly implemented by CIP and ICARDA, aims to increase the supply and provide rapid access to quality seed of the most profitable potato varieties. The project supplied seed of improved varieties and trained nearly 500 farmers, and staff of the Ministry of Agriculture, Animal Husbandry and Food (MAAHF), previously known as MOAL, and NGOs through eight courses on best practices, integrated crop and disease management, tissue culture, and marketing. The average potato yield has increased by $30 \%$ in four provinces and the introduction of fall season seed production in Nangarhar has led to the production of two crops per year. In an effort to find sustainable alternatives to cold storages, the project has constructed 15 country seed storages in four provinces.

\section{RESEARCH IN ALTERNATIVE LIVELIHOODS FUND (RALF)}

Afghanistan has been the world's major supplier of illicit opium in recent years. The production and processing of narcotic drugs grossly distorts the economy and jeopardizes the security and stability of the region as 
well as the development of Afghanistan. The Transitional Islamic State of Afghanistan adopted a National Drug. Control Strategy (NDCS) in March 2003 with the objective of reducing poppy cultivation by $70 \%$ in five years and complete elimination in ten years.

The livelihoods of around $20-30 \%$ of the rural population are at least partially dependent on the production of opium poppy. Poppy is a particularly attractive source of livelihood as it yields a high economic return, and, because it has a high labor demand, it provides access to employment, land and credit for a large number of people. If both the development and counter-narcotics objectives of the Government are to be achieved, sustainable alternative livelihoods must be identified for those who are currently engaged in illicit drug production. The United Kingdom coordinates international counter-narcotics in Afghanistan, and has adopted a plan, including research on sustainable livelihoods, to support implementation of the NDCS.

ICARDA is managing RALF, a competitive grant mechanism established in 2004 and funded by the UK's Department for International Development (DFID), to develop and promote innovative alternative livelihood options for rural Afghans currently economically dependent

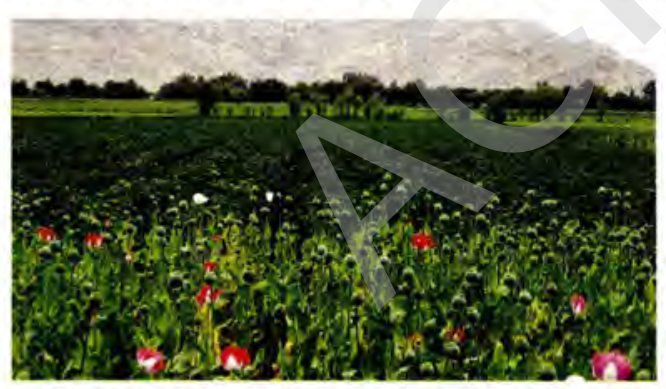

Horticulture is being promoted as an alternative to poppy cultivation. Here. a farmer grows potato (background) and poppy in the same field to compare the refurns. on opium poppy. The projects are implemented by a partnership of an international or non-Afghan research institution and an Afghan-based organization to maximize synergy between international research and local knowledge (see Appendix, inside back cover.)

\section{STRENGTHENING SEED SYSTEMS FOR FOOD SECURITY IN AFGHANISTAN}

This project, funded by the International Development Research Center (IDRC), aims to obtain a thorough understanding of local seed systems in the rainfed areas of northern Afghanistan in order to identify interventions to strengthen the informal/local seed systems and forge links with 
the formal system. The project will be implemented in two phases. Phase 1, which began in 2002, will understand the functioning of local and formal seed systems and the impacts of interventions. It will also determine the impact of Afghanistan's recent drought on seed systems and determine whether the crop genetic diversity has changed since the 1920s. Phase 2 will establish farmer participatory breeding in Afghanistan, strengthen local seed systems and develop a mechanism to link it to existing formal systems.

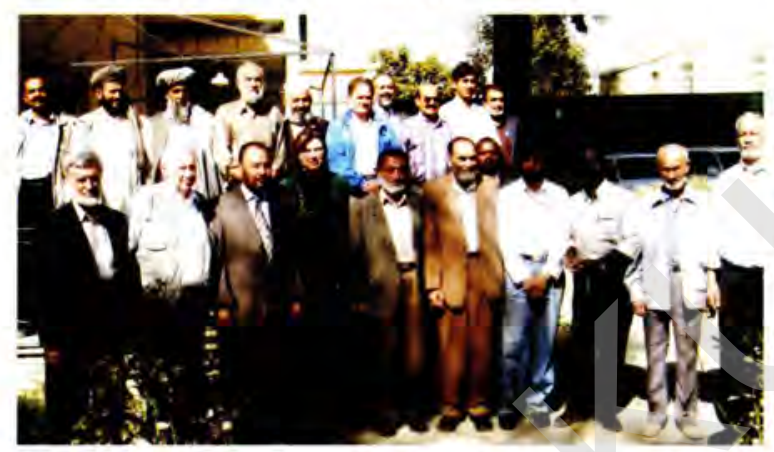

Participants of the meeting on "Strengthening Seed Systems for Food Security in Afghanistan," held on 27-29 September 2004 in Kabul.
The project conducted household surveys, focus group discussions and key informant interviews. Based on these findings, participants at a stakeholders' meeting for the project held on 27-29 September 2004 in Kabul identified four major areas for further interven-

tion: (i) improving farmers' access to good and local crop varieties; (ii) improving seed markets (seed demand assessment, promotion, marketing etc.); (iii) promoting farmer organizations and village based seed enterprises; and (iv) monitoring and evaluating project impacts. The project has also collected a total of 677 accessions of a variety of crops including wheat, barley, mung bean, cowpea, kidney bean, rice, melon and flax. Preliminary analyses suggest that there is still a large array of genetic resources in the rainfed areas of northeastern Afghanistan.

\section{COMMUNITY-BASED RESEARCH ON AGRICULTURAL} DEVELOPMENT AND SUSTAINABLE RESOURCE MANAGEMENT IN AFGHANISTAN

This project, sponsored by the OPEC Fund for International Development, promotes adaptive research in screening and identifying new varieties of cereals and food legumes, and the production of early generation seed of wheat varieties that are adapted to the agrocli- 
matic conditions of Afghanistan. Since 2003 the project has re-established a program to screen and identify new varieties, and produce early-generation seed. In 2003/2004, a total of 48 trials were conducted, and the project produced $133,774 \mathrm{~kg}$ of high-quality seed of 15 different wheat varieties that are being cultivated by farmers in the eastern and northeastern zone in Afghanistan. This seed, if properly managed, will produce some 2675 tons of wheat seed in 2005 .

Mung bean varietal frial in Sheesham Bagh research station in Nangarhar.

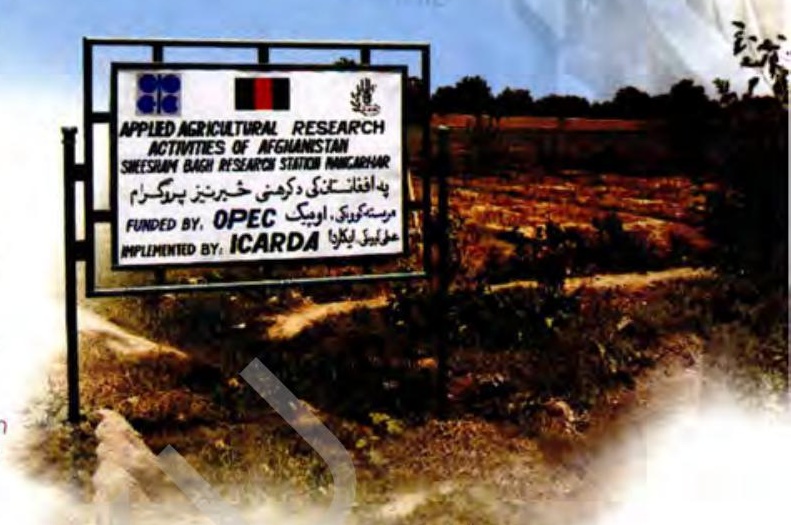

\section{HUMAN RESOURCE DEVELOPMENT}

The ability to increase and share knowledge is the most basic component necessary for human progress. As the conflict in Afghanistan spanned decades, this ability was eroded. Professionals left to find jobs in other countries and those that remained were isolated from their peers and progress. Human capacity building became an important focus for the FHCRAA and a training component was inserted into every project. Afghan researchers, staff from MOAL, agricultural univer-

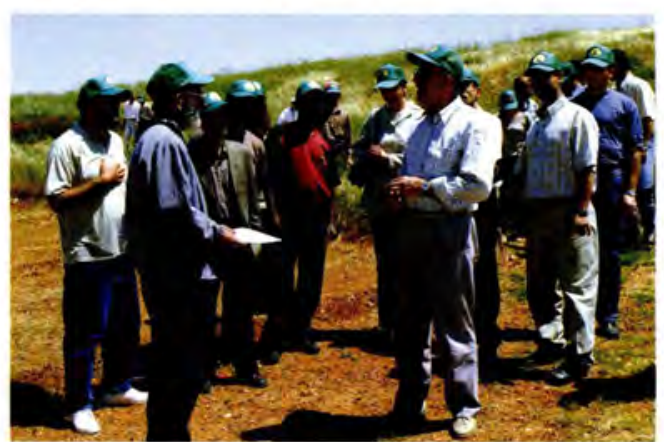

Afghanistan researchers participate in a water management training course at ICARDA. sity faculty members, and farmers have been trained in seed production and multiplication, seed enterprise development, variety management, integrated pest management, operation and management of experimental stations, use of field equipment, fertilizer and pesticide application, meteorological equipment/ 
station operation, management of water resources and improvement of water-use efficiency, advanced radio production, agricultural journalism, protected agriculture, and computer technology. Since 2002 , ICARDA has trained more than 1000 Afghan farmers through a series of headquarters and non-headquarters training courses.

In September 2004, ICARDA and the Japanese International Cooperation Agency (JICA) signed a 5-year agreement for training in Afghanistan. This "Third Country Training Program" aims to strengthen agricultural research and human resource development by organizing training courses and workshops in a variety of topics including cereal and legume crop improvement; agricultural information management; experimental design and data analysis, forage and pasture seed production; liberalization of the national seed sector; and participatory plant breeding. A workshop on seed policy and regulatory reform was held in February 2005 as part of this project.

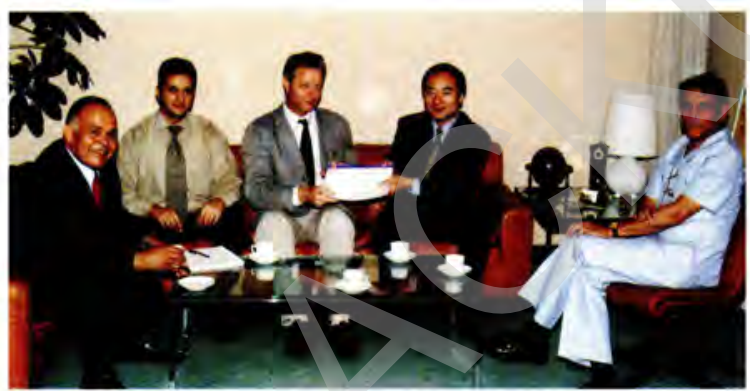

In the presence of $\mathrm{Dr}$ Mohan Saxena (right), ADG (At-Large), Mr Kazuhide Nagasawa (second from right). JICA Regional Representative in Syria, and Dr William Erskine (center). ADG (Research), exchange signed copies of the Third Country Training Program agreement for Afghanistan.

\section{ONGOING COMMITMENT}

Much has been achieved in Afghanistan since the ICARDA-led Future Harvest Consortium began its work in 2002. The hard work of the past three years has placed the FHCRAA in a position to restore Afghanistan's agricultural system, improve livelihoods and provide options for struggling farmers, and, most importantly, ensure food security in the nation.

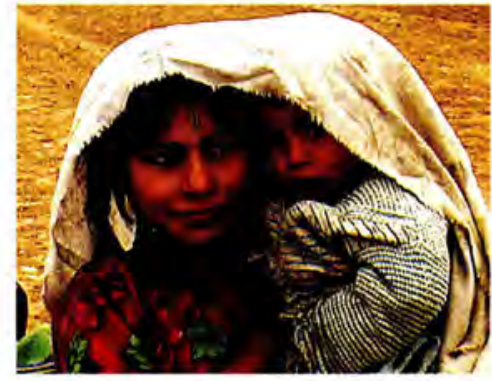

Afghanistan's future. 


\section{RALF Projects}

Implementing Agencies (lead in bold) Ist round projects (2004-2006)

Washington State University: Danish Committee for Aid to Afghan Refugees: (DACAAR): Ministry of Agriculfure and Animal Husbondry (MAAH)

Rellef International: World Vegetable Centre: Nangarhar University: Internationo Development Enterprises

Mercy Corps Afghanistan: Centre for Arid Zone Studies: MAAH (Helmand and Kandahar Provinces]

Natural Resources Institute, UK: Aga Khan Foundation

Macaulay Research Consulfancy Services Lid., UK: Mercy Corps: MAAH: ICARDA

ICARDA: Aga Khan foundation: MAAH: Macaulay Research

Catholic Rellef Services (CRS), Afghanistan: ICRISAT

2nd round projects (2005-2006)

DACCAR; Woshington State University:

MAAH

Joint Development Associates International (JDA), Afghanistan: CIMMYT: Cornell

University; Aga Khan Foundation/Balkh

Credit Union: (BCU)/World Council of

Credit Unions, Inc. (WCCU)

Novib-Oxfam, Netherlands: NGOS (AKF. CHA, Swisspeace)- Afghanistan: University of Kabul/ MAAH-Dept. of Forestry/Anadolu University-Turkey

ICARDA: Central Institute of Medicinal and Aromatic Plants (CIMAP), India: MAAH

\section{Short Tille}

Village decision driven research projec

Introduction, Evaluation and Promolion of Appropriate Crop Legumes and Vegetables for Eastern Afghanistan (CLVEA)

Restorative agriculture and rural economy research project

Innovative financial mechanisms for improving the livelihoods of rural Afghans currently economically dependent on opium poppy

Marketing of livestock and livestock products: Market demand, potential returns to producers and constraints to market access.

Improved rural incomes from befter forage production and sales of milk products

Westem Afghanistan agroenterprise action research program

Research in sustainable production and successful marketing of saffron os an alternative to oplum poppy cultivation

ncreased productivity and profitability of wheat-bosed cropping system to reduce reliance on poppy in Northern Afghanistan

Mulfi stakeholder program on natural ingredients for food. pharmaceuticals and cosmetics in Afghanistan

Culfivation of mint as a viable alternative livellhood in East and North East of Afghanistan

\section{Location}

Loghman

Nangarhar

Helmand and Kandaha

Badakhshan

Kunduz. Takhar Dalikundi, Kandaha, Heimand provinces

Baghlan

Ghor

Pashtun, Zarghun District, Herat.

Balkh, Boghian, Bodkhshan

Khost, Patika,

Badakshan, Baghlan Bamyan, Herat, Ghor, Mazar. Farah and Faryab

Baghlan, Heimand. Kunduz, Nangarha and Takhar provinces
Focus

Village organizations, livelihood analysis and identify alternatives, marketing

Legumes (soybean, mung bean) and vegefables: market analysis: market promotion

Specialty crops; festing methods of intensified production; agro-processing enterprises: feasibility study of organic export markel

Micro/small enterprise development; financio mechanisms: micro-finance/credit

nvestigation of marketing chains for livestock and livestock products; quantifying trade: identifying market opportunities

Increasing livestock productivity: foroge and milk production; milk processing: marketing

Development of market linkages and agroenterprises: high-value crop production and small-scale value-adding activities

Production, processing and marketing of satfron: growers associations

mproving wheat-based system through introduction of high value crops (e.g. oilseeds) and conservation tillage; development of market pathways and business plans for $n$ crops and value added products nities through "volue choin anolysis" of six nd ural ingredients: processing technologies analysis of international quality standards

Increased production of spearmint for culi. ary and medicinal uses: introducing new varieties of peppermint for value-added products; market analysis 


\section{Ties that Bind}

Titles available in this series:

- The United States and ICARDA

No.1

- The SARC-NVRP Cool-Season Food Legume Program in Ethiopia

No. 2

- Australia and ICARDA

No. 3

- The Netherlands and ICARDA

No. 4

- Japan and ICARDA (Eng, Jap)

No. 5

- ICARDA and the Arab World (Eng, Ar)

No.6

- Morocco and ICARDA

No.7

- ICARDA: Serving the Highlands

No.8

- China and ICARDA

No.9

- Jordan and ICARDA

No. 10

- Italy and ICARDA

No.11

- ICARDA in Central Asia and the Caucasus

No.12

- Germany and ICARDA

No.13

- Spain and ICARDA

No. 14

- ICARDA and Syria (Ar)

No. 15

- ICARDA and Ethiopia

No.16

- Sudan and ICARDA

- Libya and ICARDA

- IFAD and ICARDA

No. 19

- Algeria and ICARDA

No. 20

Single copies of these titles may be requested free of charge from: Head, Communication, Documentation and Information Services, ICARDA, P.O. Box 5466, Aleppo, Syria. E-mail: s.varma@cgiar.org 